\title{
Asia’s Mythical Middle-Class Society
}

“The explosion of Asia's middle class is stunning ... The world has never seen anything like this before; it's probably one of the biggest seismic shifts in history," wrote Singapore's Kishore Mahbubani. ${ }^{1}$

It is true that Asian lives have improved enormously these past few decades. And yet, notwithstanding such hype, Asia's human and social development is just as stunted as the continent's economic development. Despite Asia's impressive poverty reduction, over one-third of Asian citizens still live in poverty, while only $15 \%$ have made it into the middle class. Fully one-half of Asians are living in an intermediate zone between poverty and the middle class, a zone of vulnerability and precarity.

And there are factors other than raw money which are also holding Asians back from joining the middle class: the vulnerability and precarity of informal or non-regular employment; deprivations like the lack of clean drinking water, inadequate health facilities and sanitation (i.e., clean, safe and hygienic toilets); the impact of Asia's all-too-frequent natural disasters; poor access to education and the Internet; and above all Asia's appalling human rights.

The arrival of a middle-class society would be a great achievement in terms of realizing an Asian Century. But at this stage, middle-class Asia is still a myth. Only a handful of Asian countries could reasonably claim to have middle-class societies. And as economic growth prospects for Asia have faded in recent years, the impending arrival of a middle-class society is also fading into the distance. 
In this chapter, we examine the evidence for the rise of Asia's middle class. And we will conclude with a short section on Asia's super rich, a small group which is doing very well through Asia's rise, but is now suffering from some rich country problems like obesity and diabetes.

\section{Asia’s Stunted Middle Class}

There is no universal agreement on what middle class means. Economists think in terms of how much someone consumes or earns in income. Sociologists tend to reason in terms of education, occupation in a whitecollar job or other social status.

In 2010, the Asian Development Bank (ADB) published a report which defined the middle class as those living in the range of \$2-\$20 a day. ${ }^{2}$ The $\mathrm{ADB}$ concluded that the majority of Asia's middle class lived on \$2-4 day, and were part of the "lower middle class". Many Chinese just laughed. No-one could live on $\$ 2$ or even $\$ 4$ day today in a Chinese city. Shanghai and Beijing are among the world's most expensive cities.

In another report, the OECD proposed a more realistic measure for the "global middle class", being consumption or income of \$10-100 a day. ${ }^{3}$ This is of course a much more meaningful measure of the middle class, and $\$ 10$ a day is now increasingly accepted as the beginning of the middle class in emerging economies. At the same time, income or consumption of $\$ 10$ a day would not be considered middle class in any advanced Western country. In other words, middle class has become a fuzzy concept, and must be interpreted with caution.

Using the $\$ 10$ a day benchmark, some 650 million Asians could today be considered middle class. This sounds like a big number by any score. And it certainly sounds like a good market for businessmen wishing to hawk their wares. But this represents at best some 15\% of Asia's population, based on World Bank statistics. ${ }^{4}$ In short, it is far-fetched to talk about a middle-class Asia when only 15\% of Asians could be considered middle class. As the Pew Centre has highlighted, a global middle class is still more a promise than reality. ${ }^{5}$

China, the country most talked about for its emerging middle class, only has $20 \%$ of its population living on more than $\$ 10$ a day. And India and Indonesia, Asia's other two emerging giants, are even further away from having middle-class societies, with only $3 \%$ and $5 \%$, respectively, of the population live on more than $\$ 10$ a day. When you visit these countries you can experience the reality of middle-class life when you go 
shopping. For example, international companies are producing secondgrade versions of their products, like clothes washing powder, to keep prices low for Chinese customers. Of course, this washing powder won't clean your clothes like you do back home. That's why friends of mine who live in Beijing carry back first-grade products from their European and American homes just so they can wash their clothes properly.

And while emerging Asian countries are struggling to achieve middleclass societies, advanced Asian countries like Japan and Korea are seeing their middle classes recede, as they are stalked by the new rich country problems of inequality and poverty. For example, Korea has seen its middle class decline from $75 \%$ of the population in 1990 to $67 \%$ in 2013 (with the middle class defined as those earning $50-150 \%$ of the median national disposable income, an appropriate measure for advanced countries). ${ }^{6}$

\section{Middle Class in Manila}

The life of my friend Edwardo gives us some insights into the lives of those on the cusp of the middle class in the Philippines. Edwardo is a taxi driver, who earns about $\$ 14$ a day, while his wife earns small amounts by selling Tupperware and Avon products.

Edwardo has just become a grandfather at the age of 33. His 14-yearold daughter recently gave birth to a baby boy, fathered by her 16-yearold boyfriend, a fellow high school student. This is not an exceptional case. The Philippines has the highest rate of adolescent births in East Asia. The strong influence of the Catholic Church means that there is insufficient sex education and access to contraceptives.

The family of Edwardo shares a small apartment of one bedroom and one living room, which gets flooded out in the rainy season. Life is a constant struggle. Edwardo must provide for his family on a constant, daily basis. But his taxi earnings are not regular. Some days he earns more than $\$ 14$, some days he earns less and some days he earns nothing at all after waiting for hours.

Financial management is thus key to Edwardo's survival. He is well trained for that thanks to his college degree in business studies (like many in developing Asia, he is vastly overqualified for his job). But at the moment, he is two months behind on paying his rent and three months behind on his electricity bills.

Edwardo is now contemplating emigration, the lifeblood of the Philippine economy and society. He has been exploring possibilities with migration 
agencies, but their fees are expensive, at least $\$ 2500$. Then they sometimes rip off poor, naive migrants. And on top of the agency fees, there is the cost of the air ticket and pocket money to get started in a new country.

Edwardo is deeply worried. He doesn't know how he and his family can survive. Like many Filipinos, he hopes that God might help him.

\section{Escaping Extreme Poverty}

While Asia has only made limited progress in achieving a middle-class society, it is certainly true that strong economic growth has enabled millions of Asians to escape the clutches of extreme poverty. Today, according to the World Bank, if you are living on less than $\$ 1.90$ a day, you are living in "extreme poverty". This means that you don't have enough income to cover the minimum costs of life's basic needs.

On this basis, extreme poverty fell from some $61 \%$ of the total population of East Asia and the Pacific (where China is by far the biggest economy) in 1990 to only $7 \%$ in 2012, and may have even fallen further to $4 \%$ by 2015 , or 83 million persons. South Asia, dominated by India, saw a fall in extreme poverty from $51 \%$ of the total population in 1990 to $19 \%$ in 2012 , and possibly further to $14 \%$ in 2015 , or 231 million persons.

The World Bank, United Nations and others like to celebrate this extraordinary achievement. They feel that they are succeeding in the greatest challenge facing mankind, the "war against poverty". And while great progress has certainly been achieved, the $\$ 1.90$ extreme poverty line is of very little relevance to Asia's developing and emerging economies. It was calculated by taking the average of the national poverty lines of the world's 15 poorest, mainly African, countries. ${ }^{8}$ Only two Asian countries are included, Nepal and Tajikistan, while the great homes to Asian poverty, namely China, India and Indonesia, were not taken into account.

The World Bank has another, less well publicized, poverty line of \$3.10 a day, which is much more relevant to most Asian developing countries. Some refer to this as a "moderate", rather than extreme, poverty line. On this basis, Asia's progress in poverty reduction is much less impressive. Indeed, some $22 \%$ of East Asians were living on less than $\$ 3.10$ a day in 2012 , triple the $7 \%$ based on $\$ 1.90$ a day, while China's poverty rate jumps to $27 \%$ from $11 \%$. And some $55 \%$ of South Asians were living on less than $\$ 3.10$ a day, almost triple $19 \%$ based on $\$ 1.90$ a day, as India's poverty rate rises to $58 \%$ from $21 \%$. This means that in reality some $36 \%$ or 1.4 billion Asians are living in poverty. 
This still represents very impressive progress in poverty reduction, but very much less than on the basis of $\$ 1.90$. In either case, it is only the very beginning of living a decent life. If you are earning $\$ 1.90$ or $\$ 3.10$ a day, it simply means that you are unlikely to die from starvation from one day to the next. But it does not mean much more.

Indeed, the reality of Asian life is that most Asians who have escaped poverty are now caught between poverty and middle class (based on \$10 day). Fully one-half of Asians are still living in a very vulnerable and precarious situation between $\$ 3.10$ and $\$ 10$ a day. At such low levels of income, people are at risk of falling back into poverty in the event of an earthquake, flood or other natural disaster, a sudden hike in food prices, or a personal/family problem like unemployment, or health problem.

\section{Inequality Holds Back Asia’s Poverty Reduction}

The impressive reduction in Asian poverty could have been much greater had it not been for the rise in income inequality since 1990 in most of Asia, especially in Asia's population centers of China, Indonesia and India. This increasing inequality was a turnaround from the period before 1990 when economies like Hong Kong, Japan, Korea, Singapore and Taiwan were able to achieve "growth with equity". Income inequality, as measured by the "Gini coefficient", is now higher in Asia than in the rest of the world.

What has caused the increase in inequality? According to the International Monetary Fund (IMF), rapid technological change which requires high-skilled workers and displaces lower-skilled workers has been an important factor. ${ }^{9}$ Rapid economic development has also favored urban areas rather than rural areas, giving rise to "spatial inequality". Unequal access to education has been another factor as richer towns offer better education than poorer towns do, and richer families can afford a better education for their children than poorer ones do.

But there are also other factors driving Asia's yawning inequality, most notably corruption. While petty corruption is widespread on the streets of many Asian countries, it is grand corruption that enables Asia's elites to fill their pockets at the expense of the general public. We will come back to this issue in greater detail in Chap. 9. And as Christopher Ng, Regional Secretary at UNI Global Union Asia Pacific, argues the proliferation of precarious, informal and irregular work is also a key driver of income inequality. We explore this later in this chapter. 
There is much that governments can do to improve income inequality through government spending and redistribution. Moreover, it is important to improve the "equality of opportunity" to education, health and financial services which weigh on future inequality. And many governments, notably in China, are making the rights noises. But too little effort is actually being deployed. This is important, not only for enhancing the fight against poverty. Inequality can lower future investments in education and health, thereby compromising future economic prospects. It can also foster populism and weaken the support for pro-growth policies, as well as lead to social and political instability.

\section{Asia's Precariat}

Asians living on $\$ 1.90$ or $\$ 3.10$ a day don't just suffer from a lack of money. They are also exposed to vulnerability and precarity because they are typically working in the "informal sector". The informal sector of the economy is composed of enterprises which are neither registered nor regulated, and whose workers have no contract or rights. ${ }^{10}$ Minimum wage laws, collective bargaining, and health and safety standards are unheard of in the informal economy. Globalization can foster the informal economy, as multinational enterprises, notably in the garments industry, can outsource production to micro- and home-based operations to keep costs and prices low.

Some two-thirds of Asians have such low-quality jobs in the informal sector, a figure which has barely budged over the past two decades or more $^{11}$ (in comparison informal workers only account for about one-third of total in Latin America). The share of informal employment ranges from over $80 \%$ in Bangladesh and India, to $50-70 \%$ in countries like the Philippines, Thailand, China, Pakistan and Indonesia, and down to around 10\% for Hong Kong and Singapore.

Workers in Asia's vast precarious, informal economy have been called the "precariat" by political scientist Guy Standing. ${ }^{12}$ The precariat covers work in small factories, backyard mechanics, home-based producers, domestic servants, most agricultural workers, ambulant peddlers, street vendors and hawkers, casual construction workers and so on. "There are success stories about economic empowerment and entrepreneurship among the informals," writes Rene Ofreneo. "However, these are overwhelmed by the numerous sad stories about abuses, hardships and 
difficulties of worker survival in the harsh and unprotected world of the informals."

Migrants are also part of Asia's precariat. While most Asian low-skilled migrants travel outside the region, especially to the Middle East, there are large numbers of undocumented workers crossing Asia's porous borders, like the following corridors India-Bangladesh-Pakistan, China-Hong Kong, China-Indochina, Thailand-Myanmar, Indonesia-Malaysia and Malaysia-Singapore.

Most of these migrants cross borders without any legal papers or documents, and end up not only as unregistered, but also as highly vulnerable workers in the countries of destination. For example, stories abound of how migrants from Myanmar's Rohingya tribes are abused in Thailand and Bangladesh, and how Indonesian plantation workers suffer in Malaysia. Another group of the precariat is the large floating populations of internal migrants, especially in large economies like China and India. They flock to the industrial areas from the rural areas, picking up odd and casual jobs at pitifully low wages.

Most tragically, Asia accounts for $56 \%$ of the world's 21 million people who are made to work against their free will ("forced labor"), coerced by their recruiter or employer, for example, through violence or threats of violence, or by more subtle means such as accumulated debt, retention of identity papers or threats of denunciation to immigration authorities. Asia is also home to more working children than any other region in the world. An estimated 122 million Asian children aged 5-14 years are compelled to work for their survival. Millions are not enrolled in school at all. Although there has been progress in reducing child labor in many countries in the region, the problem persists.

It would be nice to think that economic development will lead to a reduction in Asia's precariat. But the reality is, as mentioned before, that there has been virtually no decline in emerging Asia's precariat population over these past two decades. Moreover, Japan has seen its widely admired system of life-time employment fritter away, and be gradually replaced by non-regular work contracts. Another disturbing trend is that each successive financial crisis, from the 1997 Asian Financial Crisis to the 2008 Global Financial Crisis, has seen a rise in precarious employment in Asia, and also in the US and other Western countries. Workers with regular jobs get laid off when crisis strikes, and are re-hired on irregular contracts when the economy recovers. 


\section{Surviving on the Threshold of Poverty IN BANGLADESH}

What is life like if you are surviving on $\$ 1.90$ or even $\$ 3.10$ a day in one of Asia's developing countries? Life involves a complex process of financial management, according to the authors of "Portfolios of the Poor". ${ }^{13}$

When you are living on such a low income, you spend most of your money on the basics, especially food. There is one big problem, though. Like the case of Edwardo, you are very unlikely to receive a steady check or payment from your boss. Since you are surely casually or part-time or self-employed in the informal sector, you make more on some days, less on others, and often get no income at all.

The government offers you very limited help, and when it does, the quality of assistance is apt to be low. Your greatest source of support is your family and community, though most often you'll have to rely on your own devices!

So how do the poor budget? In particular, how do they make sure that there is something to eat and drink each day? How do they deal with emergencies? How can they be sure that they can pay for the doctor and drugs when their children fall sick? How do they put together the funds for big ticket items like a home and furniture, education and marriage for their children, and some income for themselves when they are too old to work?

The evidence shows that for the poor, financial management is a fundamental and well-understood part of everyday life as they cope with incomes which are small, and often highly irregular and unpredictable. Indeed, even those living on less than 1 dollar a day per person rarely consume every penny of income as soon as it is earned.

Money management by the poor involves: storing savings at home, with others, and with banking institutions; joining savings clubs, savings-andloan clubs and insurance clubs; and borrowing from neighbors, relatives, employers, moneylenders or financial institutions. At any one time, the average poor household has a fistful of financial relationships on the go.

The case of Hamid and Khadeja, a poor couple living in a Bangladeshi village, provides a window on financial management by the poor. When their first child was born, they moved to Dhaka, nation's capital, where they settled in a slum. After spells as a cycle-rickshaw driver and construction laborer and many days of unemployment, Hamid whose health was not good was taken on as a reserve driver of a motorized rickshaw. Khadeja 
stayed at home, earning a little from taking in sewing work. Home was one of a strip of small rooms with cement block walls and a tin roof, built by their landlord on illegally occupied land, with a toilet and kitchen space shared by the eight families that lived there.

They earned on average $\$ 70$ a month, almost all by Hamid. One-fifth of the $\$ 70$ was spent on rent (not always paid on time), and much of the rest went toward the most basic necessities of life-food and the means to prepare it. This put them among the poor people of Bangladesh, but not the very poorest.

Hamid and Khadeja are an unremarkable poor household. But they are very active money managers. They had built up reserves in six different instruments, ranging from $\$ 2$ kept at home for minor day-to-day shortfalls to $\$ 30$ sent for safe-keeping to Hamid's parents, $\$ 40$ lent out to a relative, and $\$ 76$ in a life insurance savings policy. In addition, Hamid always made sure he had $\$ 2$ in his pocket to deal with anything that might befall him on the road.

Hamid and Khadeja are also borrowers, with a debt of $\$ 153$ to a microfinance institution and interest-free private debts to family, neighbors, and Hamid's employer totaling $\$ 24$. They owed money to the local grocery store and to their landlord. Khadeja was even acting as an informal banker, or "money-guard", holding $\$ 20$ at home that belonged to two neighbors seeking a way to keep their money safe from their more spendthrift husbands and sons. Hamid himself also used a money-guard, storing $\$ 8$ with his employer while waiting for an opportunity to send it down to the family home.

In addition to saving, borrowing and repaying money, Hamid and Khadeja, like nearly all poor and some not-so-poor households, also saved, borrowed and repaid in kind. Khadeja, sharing a crude kitchen with seven other wives, would often swap small amounts of rice or lentils or salt with her neighbors. She would keep a note of the quantities in her head, and so would her partners in these exchanges, to ensure that their transactions were fair over the long haul.

The case of Hamid and Khadeja shows that people with low and irregular incomes can, with some difficulty, cope and survive on $\$ 1.90$ or $\$ 3.10$ a day. But their financial management is a hazardous process which depends on the reliability, kindness, goodwill and norms of mutual obligation of their network of friends, family and colleagues. Fortunately, some microfinance institutions are now stepping into this space to provide financial services to the poor. 


\section{Poverty in the Midst of Prosperity: The Case of Singapore}

Any visitor to dazzling Singapore might be shocked to learn that a quarter of Singaporeans live in poverty, even though GDP per capita in the city state is the highest in Asia, and one of the highest in the world. And the poverty rate would be much higher if the situation of low-skilled migrants were included in analysis of the issue.

The life of Patricia, a Singaporean nurse, and her unemployed partner, Sham, illustrate the challenges of a life of poverty. Patricia works as a fulltime nurse in a governmental hospital, and earns just $\$ \$ 1400$ a month. She pays $S \$ 850$ a month to rent a non-air-conditioned room in an apartment at Admiralty, in the north of Singapore, a 90-minute commute by public transport to her workplace.

Patricia's monthly rental does not entitle her to the use of her landlord's kitchen, so she and Sham must eat out for all their meals, often at McDonald's. Unfortunately, she cannot afford a small, two- bedroom condominium unit in the city center which would cost $\$ \$ 5000$ or more. Life can be hard in the world's most expensive city. ${ }^{14}$

Singapore's poor can also be found selling packets of tissues outside food centers. Or spending the night on benches near their jobs to save the transport fare home- they are known as "sleepers". Or collecting empty soft drink cans out of trash bins.

Kishore Mahbubani, dean of the Lee Kuan Yew School at the National University of Singapore, wrote in 2001: "There are no homeless, destitute or starving people in Singapore. Poverty has been eradicated, not through an entitlements programme (there are virtually none) but through a unique partnership between the government, corporate citizens, self-help groups and voluntary initiatives". ${ }^{15}$

This comment is plainly misleading.

Inequality and poverty have indeed been deteriorating in Singapore, according to a study by the Lien Centre for Social Innovation and the Singapore Management University. The bottom 20\% of Singapore residents saw their real median incomes fall by $8 \%$ from 1998 to 2010 , while those in the top $20 \%$ increased by $27 \%$. Singapore does not have a minimum wage. Thus the rate of inequality has risen dramatically, and is the second highest in Asia, after Hong Kong, and is one of the highest in the advanced world. 
The consequence for Singapore's poverty situation is dramatic. Some $10-15 \%$ of Singapore's population are unable to meet their basic needs of food, clothing, shelter and other essential expenditures, with their monthly income below S\$1250-1500. Most of these people include "working poor", unemployed poor households and poor retirees.

If the notion of basic needs is expanded to include in-school education, improving skills, and the purchase of goods like computers, Internet connection or mobile phones, about $25 \%$ of Singapore's population is living in poverty, below $\$ \$ 2500-3000$ a month, sharply up over the previous decade. These expenditures are necessary to invest in human capital and create the possibility of social mobility or a life beyond continued basic subsistence for adults or children of the next generation.

It is hard to escape the conclusion that Singapore's poor, as well as its lower-skilled migrants, are there to suffer and serve Singapore's elite, which now counts 188,000 millionaires and 20 billionaires. Singapore has the highest concentration of millionaires per capita in the world.

Another sad reality is that most Singaporeans are not aware of the scale and depth of poverty in Singapore. And the Singapore government provides very much less assistance to the poor than do governments in other advanced countries. Thankfully, there are many civil society anti-poverty initiatives like "Singaporeans Against Poverty", launched by the Catholic group, Caritas.

\section{Japan's Two-Track Job Market and Vulnerability}

It is not only Asia's poorer countries which are afflicted with vulnerability and low-quality jobs. Advanced countries like Japan and Korea are also suffering from similar problems. In Japan, the share of nonregular workers in the economy has almost doubled from $20 \%$ in 1994 to $38 \%$ in $2016 .{ }^{16}$ The category of irregular workers includes fixedterm, part-time and dispatched workers, the latter being persons employed by temporary worker agencies who are sent to firms on a fixed-term basis. Over $50 \%$ of temporary and dispatch workers would prefer a regular job.

In the hypercompetitive world economy, companies are now resorting more and more to irregular workers who are easy-to-hire and easy-to-fire. The traditional Japanese system of life-time employment, seniority-based wages, firm-based training and regular job rotation, which served Japan so 
well during its high-growth period, is increasingly seen as inappropriate in the world of today.

Non-regular employees typically bear the brunt of the cyclical ups and downs in the economy. Japan's women are the biggest victims of nonregular employment, reflecting the discrimination from which women suffer in Japanese life. More than half of female employees have non-regular jobs, which means that they account for two-thirds of total non-regular employees. Non-regular work is frequent among youth and older workers; the latter are often re-employed at lower wages after they reach the occupational retirement age (typically 60 ) and until they reach the public pension age (65).

While non-regular employment may have much naive appeal to Japan's enterprises, it comes with great costs to the country's economy and society. Non-regular employees benefit much less from firm-based training, and once you are a non-regular employee, chances are you will be a nonregular employee for life. Non-regular employment is not a stepping stone to regular employment. In other words, the phenomenon of non-regular employment is creating an economic underclass, which is undermining the nation's long-term prosperity.

Non-regular employees systematically earn much lower incomes, about $40 \%$ less for equivalent jobs, and have much less access to social welfare like unemployment and health insurance even though they have precarious jobs. This is a key factor fracturing Japan's society, as its relative income poverty and inequality are now among the highest of the advanced OECD countries. ${ }^{17}$ The lower income of non-regular workers is also discouraging marriage and hence reducing Japan's chronically low fertility rate, the main factor behind its dramatically aging population. It is not surprising that surveys have found that well-being and happiness level reported by non-regular workers is below that of regular workers and the self-employed.

Over the years, there have been many proposals to break down this dualism in the Japanese labor market (and society), such as by increasing social insurance coverage and upgrading training programs for nonregular workers and reducing effective protection for regular workers. But as with many of Japan's intractable policy debates, it's another case of all talk and little action. This rise in non-regular employment means that, as in Korea, increasing numbers of Japanese are also slipping out of the middle class. 


\section{A Deeper Look at Poverty Reduction and Asia’s Toilet Crisis}

There is a lot more to poverty, vulnerability and the middle class than whether you are earning $\$ 1.90, \$ 3.10$ or $\$ 10$ a day. Many Asians who earn such incomes may also suffer from other deprivations like no access to clean drinking water, clean and safe toilets, education for their children, basic healthcare facilities or personal security. Large countries like India, Indonesia and Pakistan have some of the worst records in these respects.

Can the citizens of these countries be happy with $\$ 1.90$ a day or more in their pockets, if their wives die in childbirth, if their children die before they reach five years or if their children suffer from malnutrition?

The lesson is that Asia's rapid economic growth has been very effective at putting money in people's pockets. But Asian governments have been much less effective in providing their citizens with the basic social services that they need and deserve.

Perhaps one of the most egregious deprivations from which many Asians suffer is the lack of "improved sanitation" or, in plain English, clean, safe and hygienic toilets. Today, some 1.7 billion or $42 \%$ of the region's population still lack access to improved sanitation, according to the ADB. ${ }^{18}$

And while the region's toilet deficit was mainly a rural phenomenon, this problem is now becoming increasingly acute in urban areas, with tens of millions of people now migrating every year into slums and other infrastructure-poor urban areas.

Close to half of Asia's “toilet-poor" population lives in India. This country has nothing short of a "toilet crisis". In fact, many more Indians have access to a cell phone than to a toilet!

This emerging economic giant reportedly has the world's longest toilet queue, with some 775 million people without access to clean, safe and hygienic toilets. ${ }^{19}$ China comes in runner up with 330 million people without toilets, while Indonesia is fourth-place (100 million), Pakistan sixth place (69 million) and Bangladesh seventh place (63 million).

If these 775 million Indians without toilets, more than $60 \%$ of the nation's population, were lined up in a queue, it would stretch from the earth to the moon and beyond. In percentage terms, the toilet situation in India is much worse than in virtually all other Asian countries. For example, in Cambodia $58 \%$ of the population is without toilets, in Nepal 54\%, 
in Bangladesh and Indonesia 39\%, the Philippines 26\%, China 24\% and Vietnam 22\%.

Among those Indians that do have toilets, there are many millions who use homemade toilets, on a raised platform inside the house, which are not connected to a sewerage network or pit. So this human waste is then cleaned by poor Dalit women ("untouchables") who face horrific discrimination. India also wins the world prize for the most number of people practicing open defecation, with 173 million people relieving themselves behind bushes, in fields, by roadsides, or at some other unsavory and unsafe place in this beautiful country.

Lack of access to clean, safe and hygienic toilets is a big problem for many reasons. It can have dramatic effects on people's health through pollution of water supplies, which renders them unfit for drinking, irrigation and other purposes. About $80 \%$ of untreated sewage in India reportedly flows into rivers, lakes and ponds, and then often seeps underground thereby polluting drinking water sourced from groundwater.

Diarrhea is one major problem, which is caused by poor sanitation and hygiene practices and unsafe drinking water. It is a major cause of child malnutrition, disease and death. Nearly half of India's under-five children are stunted (too short for their age), with poor sanitation being a major underlying cause. More than 140,000 children younger than five years die each year in India from diarrhea. India also has high rates of maternal and newborn mortality linked to sepsis.

Open defecation also puts the safety of women and girls at risk. They are often subject to sexual harassment, physical assault and rape on the way to and from their defecation site.

Indian Prime Minister Narendra Modi announced in October 2014 his Swachh Bharat (Clean India) Mission. The objective is to deliver a toilet to every household and end open defecation by 2019, the 150th anniversary of Mahatma Gandhi's birth, and to educate people about the longterm health and economic benefits of using a toilet.

Some progress is being made, but the government's toilet construction is way behind schedule, and may take an extra ten years. But building toilets is the easy part. The waste management system across large parts of the country is a stinking mess. Most villages have no systems for disposal of drainage water, and urban areas cannot manage their waste.

But what is more disturbing is that, according to many reports, the new toilets are frequently not used. Many people consider toilets to be unclean, 
and prefer open defecation. They have been demolishing the new toilets or using them for other purposes.

Hindu tradition encourages defecation in the open, far from home, to avoid ritual impurity. So many people, notably in the Hindu-dominated Gangetic plains, today still show a preference for going in the open-even if they have latrines at home. Some Indians argue that open defecation is more wholesome, healthy and virtuous life. It is pleasurable, comfortable and convenient!

In short, the government must also tackle the cultural reasons for India's toilet crisis. Simply building the toilets won't be enough. Tackling India's toilet crisis requires a multifaceted strategy, with strong leadership. It requires an effective public education campaign, investment in sewerage systems as well as toilets, and cooperation between different levels of government in this vast country.

\section{A Deeper Look at Poverty Reduction and the Impact of Natural Disasters}

Now what happens if you have your $\$ 1.90, \$ 3.10$ or even $\$ 10$ a day in your pocket, but every couple of years it gets washed away in a flood, blown away in a typhoon or lost in an earthquake. Or what about if you have to use those few dollars to rebuild your life after a natural disaster because you have very few other assets to fall back on, no insurance, or because you receive insufficient help from your government or international donors.

Fortunately, the ADB has estimated for us the impact on Asian poverty from natural calamities like floods, landslides, tsunamis, earthquakes, droughts and storms. ${ }^{20}$ When the vulnerability to such natural calamities is taken into account, over 400 million extra people were estimated to live in poverty in 2010, with more than half of them being in China, a country which is highly exposed to flooding. And since natural calamities are a growing phenomenon in Asia, this estimate of 400 million would only have increased since 2010. In short, natural disasters are yet another untold side of Asia's poverty.

It is hardly surprising that natural disasters should have such an impact on Asia's poverty and middle-class aspirations. The Asian continent is the most disaster prone in the world. ${ }^{21}$ Indeed, after the US, China, India, the Philippines and Indonesia are the countries the most hit by natural 
disasters. ${ }^{22}$ Active tectonic plate movements in the Pacific and Indian Oceans are a source of major earthquakes and tsunamis, while Indian and Pacific Oceans also regularly generate tropical cyclones and typhoons.

Over 2 million Asian people died from natural disasters between 1970 and 2014 , some $57 \%$ of the global fatalities, with earthquakes and tsunamis being the main cause of deaths, according to the UN. The following mega disasters accounted for most natural disaster fatalities in recent years: the 2004 Indian Ocean tsunami (more than 200,000 deaths), Myanmar's 2008 Cyclone Nargis (140,000 deaths), Bangladesh's Cyclone Gorky in 1991 (140,000 deaths), China's 2008 earthquake (90,000 deaths), Pakistan's 2005 earthquake $(75,000$ deaths) and Japan's 2011 earthquake/tsunami (20,000 deaths).

What's more, some 6 million people from the region were affected by disasters over the same period, with floods and drought affecting the highest number of people. The economic cost from natural disasters over this 45-year period was over $\$ 1.15$ trillion, with earthquakes, tsunamis, floods and storms being responsible for the lion's share. Indeed, the economic losses from natural disasters have been surging in recent years. And with climate change contributing increasingly to weather instability, the frequency of natural disasters will only increase.

Many organizations have flooded the world with recommendations for dealing with natural disasters. For example, the $\mathrm{ADB}$ recommends reducing population exposure to natural disasters, exploiting early warnings and strengthening resilience. ${ }^{23}$ This is indeed wise advice. But it is much easier said than done.

In particular, the 2016 floods in China show how far behind the curve this emerging superpower is when comes to dealing with natural disasters at home. Hundreds were killed, more were missing and tens of millions affected, while vast areas of agricultural crops were destroyed. Chinese citizens complained of inadequate early warnings, illegal building in exposed areas, poor or non-existent drainage systems, government incompetence and cover-ups, and censorship of their social media reports.

While some officials have been fired, and the national government expressed sympathy, it is unclear whether serious efforts are being made to improve China's natural disaster risk management. Obfuscation and coverup is the Chinese government natural response to any disaster. One of the most notorious cover-ups was regarding the 5335 students who died in the 2008 Sichuan earthquake due to the substandard construction that caused the collapse of more than 7000 classrooms in the region. 


\section{Asia's Education Divide}

A well-educated population is key to a middle-class society. And on this score, a good number of East Asian countries seem to have strong foundations for a middle-class society, based on OECD's latest Programme for International Student Assessment (PISA) survey, which evaluates the knowledge and skills of the world's 15-year-olds. But many questions are being asked about the real quality of these apparently successful Asian education systems. After all, Asia's elite are proud to see their kids to school in North America, Australia and the UK. And at the same time, there are just as many other Asian countries which have poor education systems.

PISA 2015 tested students in 72 countries on science, maths and reading. Students from Singapore came top in science, the principal focus of PISA 2015. The OECD reports that one in five Singaporean students masters the most advanced scientific problems and demonstrates that they can think like scientists. Six other Asian economies-Japan, Taiwan, Macao, Vietnam, Hong Kong and China (based on Beijing, Shanghai, Jiangsu and Guangdong)-make it into the top ten, along with Estonia, Finland and Canada, the only Western countries to do so.

Disturbingly, the OECD reports that only in Canada, Estonia, Finland, Hong Kong, Japan, Macao, Singapore and Vietnam do at least nine out of ten 15-year-old students master the basics that every student should know before leaving school. Germany and the US, which have two of the world's leading economies, are only ranked 16th and 25th, respectively. When it comes to mathematics, Singapore, Hong Kong, Macao, Taiwan and Japan were the five highest performers in PISA 2015, while Singapore, Hong Kong, Canada, Finland and Ireland topped reading.

How did these Asian countries do so well? According to the OECD, top performers, notably in Asia, place great emphasis on selecting and training teachers and prioritizing investment in teacher quality, not classroom sizes. They also set clear targets and give teachers autonomy in the classroom to achieve them. Children whose parents have high expectations perform better: they tend to try harder, have more confidence in their own ability and are more motivated to learn.

Others contend that the success of these Asian economies just reflects rote learning, memorization and immense drilling for tests. It is certainly true that students from these high-performing Asian countries are often sent to night school, a source of great psychological pressure. 
The strong performance of China in three consecutive editions of PISA, together with the relatively poor US scores, has opened a lively debate on the relative merits of the two education systems. It is after all curious that Chinese families should be sending over 300,000 students to US schools. Even Chinese President Xi Jinping reportedly sent his daughter to Harvard.

Some Chinese leaders have made some relevant comments. Liu Jinghai, principal at a Shanghai Middle School, reportedly admitted that the muchfeared college entrance exam-known as the gaokao-is all simply about memorization and rote learning. And at a conference in Beijing, ${ }^{24}$ Cheng Siwei, Former Vice Chair, Standing Committee, Chinese National People's Congress, said that Chinese students are good at passing tests, but much less good at critical thinking and creativity. He argued that China has much to learn from the West in that regard.

However, the greatest problem in Chinese education may be the role of propaganda, censorship and ideology - things which do not affect the OECD study which does not focus on the social sciences and liberal arts. For example, the Great Leap Forward, the Cultural Revolution and the Tiananmen Square incident have been strictly taboo in studies of Chinese history. And since the 1989 Tiananmen Square incident, "patriotic education", which emphasizes China's victimhood at the hands of Western and Japanese colonial powers and the "century of humiliation" from the Opium Wars to the end of World War 2, has been a key element of Chinese education. The Chinese government has always considered education as an important means of ideological control.

Under the current leadership of President Xi Jinping, there has been a toughening in education policies as part of the government's efforts to stamp out dissent. The education minister Yuan Guiren has called for the banning of all foreign textbooks that promote Western values. President $\mathrm{Xi}$ has called on universities to improve their Marxist ideological and political work.

The relative academic freedom that most Chinese universities enjoyed is now under threat, as topics like press freedom, civil society, human rights and multi-party democracy constitutionalism are now "no speaks". Some Chinese professors who have criticized the Communist government have been fired or even jailed. Predictably, there has been a surge in Chinese applications to study at foreign universities.

Following the 2014 "Umbrella" protest movement, Chinese Communist Party control has now reached the Hong Kong education 
system, which had always enjoyed academic freedom. Professors who have been critical of the Beijing and Hong Kong governments are now being disciplined, and academic freedom is now also being eroded.

Turning back to the OECD's PISA study of 72 countries, you will find another group of Asian countries, namely Malaysia, Thailand and Indonesia well down in the bottom half of the list. These countries have a great deal of work to do before human capital can become a key driver of economic development and middle-class societies. As the OECD said in other reports, "half of Thai students in school are not acquiring the basic skills required for their own success and the country's continued development," 25 and "Over $50 \%$ of Indonesian fifteen year olds do not master basic skills in reading and mathematics." 26

Moreover, the absence of India in PISA 2015 is striking. In fact, two Indian states-Tamil Nadu and Himachal Pradesh-participated in PISA 2009. Although they are among the best-performing states in India, they were ranked in the bottom three participants, along with Kyrgyzstan, for all three criteria. But rather than using the PISA exercise as a useful tool for measuring, and tracking over time, the nation's education, the Indian government decided to blame the PISA test, which it considers to be unfair because it does not take account of India's sociocultural milieu.

Despite the government's reaction, these very low scores square with all other indicators which suggest that India has an appalling education system. An ADB 2010 study showed that Indian children had the lowest number of years schooling out of 12 leading countries from developing Asia. India's average number of years schooling (for the population aged 15 years and above) was 5.13 years in $2010 .{ }^{27}$ This is well below the average for "Emerging Asia" (7.05 years), and even much further below the 11.0 years of developed countries. The results of this important ADB study would be even more damning if the ADB could have measured the quality of education, as well as the quantity.

\section{Asia's Digital Divide}

Access to the Internet is increasingly seen as a human right and a mark of middle-class status. But less than half of Asians use the Internet.

The Internet is indeed the fundamental technology for modern life. It can provide citizens with education, entertainment, social connections, e-government services, awareness of world and local events, and transparency about the activities of government, business and society. 
Thanks to the Internet, consumers can enjoy variety, and time and cost savings. And business benefits greatly from the Internet for global operations management, customer management, and analyzing and accessing new markets. Government can deliver and manage public services through the Internet, which can also facilitate policy analysis and implementation.

In short, the Internet is transforming the very nature of our economies and society, with profound impacts on GDP growth. But as with education, there are two distinct Asias when it comes to access to the Internet.

One Asia is that of the tech-savvy young population of Internauts who are developing and moving faster than the rest of the world, especially in Japan and Korea which have Internet penetration rates between $84 \%$ and $86 \%$, like the US and Germany. But the overall reality is that more than half of Asia's 4 billion citizens still do not use the Internet, according to a McKinsey\&Company. ${ }^{28}$

Some $85 \%$ of India's population of 1.3 billion do not use the Internet, despite all the hype of high-tech India. In China, the much vaunted emerging great power, $54 \%$ of the population of 1.4 billion are not online. And in Southeast Asia's leading country of Indonesia, $84 \%$ of its population are also not online. The situation is fairly similar in other populous Asian countries like Pakistan, Bangladesh, the Philippines, Myanmar, Vietnam and Thailand.

Not surprisingly, the offline population is disproportionately rural, low income, elderly, illiterate and female. And most tragically, in most countries religious and ethnic minorities are virtually excluded from the Internet-these groups are also not surprisingly virtually excluded from their country's political processes. Of Nepal's Madhesi group, only $1 \%$ are connected to the Internet, for China's Yi group the figure is $2 \%$, Nepal's Muslims 2\%, China's Bouyei 4\%, India's Kashmiri Muslims 4\%, the Philippines' Moro 5\% and Indonesia's Papuans 9\%. ${ }^{29}$

There is much more that governments could do to improve access to the Internet, like improving affordability, education, infrastructure, notably for mobile Internet coverage or network access, and electricity. For example, in India, nearly 1 billion people still cannot afford the cheapest mobile data plans. And literacy rates are particularly low in Bangladesh, India and Pakistan, especially for women.

Electrification is poor in many Asian countries. About $70 \%$ of the mobile connections in India and China are on $2 \mathrm{G}$ networks, with potentially limited mobile Internet capabilities. Any visitor to China can tell you 
how hellishly slow Internet speeds are, and that it is impossible to access Gmail in China.

With the exception of China, the majority of Internet content and services consumed in Asia's developing countries originates from outside the country. This means that foreign language capability, rare in many countries, is necessary to use the Internet.

While deep digital divide now exists between Asia and the advanced world, and between Asian countries, too many of Asia's non-democratic governments are imposing restrictions on freedom of the Internet. Only two Asian countries, Japan and the Philippines, are classified as having Internet freedom, out of the 15 Asian countries covered in a Freedom House report. ${ }^{30}$ China was the worst abuser of Internet freedom in this report that surveyed 65 countries globally, representing $88 \%$ of the world's Internet user population. Other notorious cases in Asia were Vietnam, Pakistan, Thailand and Myanmar.

"Cyber sovereignty" is one of the high priorities of Chinese President $\mathrm{Xi}$ Jinping, as netizens are now prosecuted with "unprecedented" intensity for their offending content. There would be 84 netizens in Chinese jails as of September 2015, according to Reporters Without Borders. Xi has declared that the Internet has become the main battlefield for public opinion struggle. The Chinese Communist Party propaganda department and other agencies employ thousands of people to monitor, censor and manipulate content. China is also a major global source of cyberattacks.

Vietnam is another country classified as "not free", and is one of the world's worst jailers of bloggers. And since Thailand's military coup in 2014, harassment and arrests of Internet bloggers and users has skyrocketed.

\section{Asia's Appalling Human Rights}

One of the hallmarks of a middle-class society should be the protection of human rights by sound legislation and their fair enforcement by the authorities. Nowhere in this world can you find a perfect situation for human rights, most notably in the US, that eternal preacher of human rights. Most regrettably, many people in positions of power will exploit this power by abusing the human rights of weaker people. And when it comes to human rights, Asia has never been a beacon. ${ }^{31,32,33}$

Asia has of course the notorious case of North Korea, the most repressive country in the region. A United Nations Commission of Inquiry in 2014 found that the North Korean regime practices extermination, mur- 
der, enslavement, torture, imprisonment, rape, forced abortions and other sexual violence. North Korea also has secret gulags for opponents of the regime.

As appalling as the case of North Korea might be, what is perhaps most disturbing is the lack of meaningful progress, and indeed the recent regression, in human rights in Asia's most dynamic economies. Political scientists imagine that human rights would improve in tandem with economic development and prosperity. In today's Asia, however, there are many grounds for disappointment.

It is true that Chinese citizens enjoy a much broader range of freedoms than they did just a few decades ago, especially under the regime of Mao Zedong. The Chinese can travel and study overseas, have relative freedom of movement within their country and have access to the Internet, despite its censorship. But this authoritarian state, which has always employed repression to maintain its grip on power, has only ramped up its repression under the regime of President Xi Jinping. Indeed, as China's economy and society have become more sophisticated, so have the instruments of human rights abuse and repression. Chinese citizens now talk about China becoming more and more like North Korea, a country they despise.

The most important policy initiative of President Xi has been his anticorruption campaign. Rampant corruption on an industrial scale has been perhaps the greatest abuse of the Chinese Communist Party, and President $\mathrm{Xi}$ believes that this is a major threat to the Communist Party's rule. But as laudable as the anti-corruption campaign may seem, those accused and prosecuted are rarely being given a fair trial. Most observers believe that Xi is using the anti-corruption campaign as a ruse to eliminate his political enemies. At the same time, civil society groups that expose corruption are invariably put in jail and prosecuted themselves.

More generally, Xi has launched a widespread crackdown on lawyers, activists, journalists and civil society groups who are seen as a threat to the government. Torture of detainees remains widespread. The treatment of Nobel-prize winner Liu Xiaobo, who was denied potentially lifesaving treatment, is testimony to how badly opponents of the regime can be treated. Forced confessions on the television, including by foreigners, are now increasingly common. While these confessions are seen as an obvious sham, they contribute to an atmosphere of fear of the Communist Party authorities. Censorship of the Internet and other media is intensifying, and journalists and others who are seen to be spreading rumors are punished. 
Beijing has also been spreading its net beyond its borders in the search for threats to the Communist Party's grip on power. Five Hong Kong booksellers who were selling material critical of China were abducted to mainland China in 2015. This is just one example of the steady encroachment of the Communist Party on Hong Kong's freedoms, following the territory's "Umbrella Revolution" movement. The government successfully pressured Thailand to repatriate Chinese Uighur men back to China and also pressured Kenya to send some alleged Taiwanese criminals to China.

Freedom of religion is under even greater threat, with the campaign against Christianity intensifying through the removal of crosses from churches and the demolition of some churches in Zhejiang Province, the heartland of Chinese Christianity. Members of Falun Gong and other sects continue to be harassed and punished, while Tibetans and Uighurs continue to suffer from discrimination, repression, human rights abuses and restrictions on personal movement.

China's noxious attitude toward human rights is also evident at the UN Human Rights Council, as the pressure group Human Rights Watch has argued, where "China continues to act as a spoiler, blocking greater scrutiny of human rights situations in other countries, including Belarus, Iran, North Korea, Syria, and Ukraine."

But what is perhaps most disheartening about China's human rights situation is the relative silence on the matter by Western governments. They prefer to do profitable business with China, while only paying lip service to human rights.

Vietnam's trajectory is often compared with China's. And although it started its economic rise sometime after China, it has enjoyed similar rapid economic growth and poverty reduction, thanks to exports and foreign direct investment. But Vietnam is also similar to China in that human rights are not improving either. In the words of Human Rights Watch, Vietnam's human rights are "dismal".

The Vietnamese Communist government places great restrictions on freedom of speech, opinion, press, association and religion. The state has firm control over the media, the judiciary, and political and religious institutions. As in China, the government has been cracking down on independent writers, bloggers and rights activists seen as threatening to the ruling Communist Party.

Malaysia and Thailand are Asia's two great disappointments when it comes to human rights. Both have enjoyed great economic growth, 
achieved middle-income status and virtually eliminated extreme poverty. But both are now mired in middle-income traps and political crises, with human rights sadly deteriorating.

Malaysia's respect for human rights has been "plummeting", in the words of Human Rights Watch, as the crackdown on human rights defenders, activists, political opposition figures and journalists intensifies. And yet, Malaysian citizens have every reason to protest against the government. A government-owned investment fund, 1Malaysian Development Berhad (IMDB), whose board of advisors is chaired by Prime Minister Najib, has been severely tainted by a scandal involving allegations of massive corruption.

In February 2015, the Malaysian Federal Court upheld the conviction and five-year sentence of Anwar Ibrahim, a leading opposition figure, on sodomy charges. This "politically motivated prosecution and jailing" (in the words of the US State Department) is widely perceived as merely an attempt to weaken Malaysia's political opposition, at a time when the ruling United Malays National Organisation (UMNO) is progressively losing its grip on power. In October 2015, the United Nations Working Group on Arbitrary Detention determined that Anwar was being arbitrarily detained and demanded his immediate release and reinstatement of his political rights.

Thailand has never been a paragon of virtue for human rights. But things took a giant turn for the worse in May 2014, following a military coup. Thailand is now in the grip of deepening authoritarianism, as freedom of assembly, expression, association and the press are under assault. The lese majeste (insulting the monarchy) law is now subject to increasingly harsh and arbitrary enforcement.

Indians are proud of having the world's largest democracy, an active civil society, vibrant media and independent judiciary. But in many respects human rights are simply lousy in India, and they are not getting any better under the administration of Prime Minister Narendra Modi.

Muslims and Christians have been under attack from extreme rightwing Hindus, and the government has been doing very little in their defense. Indeed, leaders of the ruling Bharatiya Janata Party (BJP) have made inflammatory remarks against minorities. Many artists, writers and scientists have returned national honors in protest at the climate of growing intolerance. Minorities like Dalits and tribal groups are also subject to discrimination and violence. Violence against women, especially rape and murder, continues to run at epidemic proportions. 
Freedom of expression by civil society groups and the media who criticize the government has also been under threat from authorities. Human rights defenders face arbitrary arrests and detentions. According to the US State Department, some of India's most significant human rights problems are "police and security force abuses, including extrajudicial killings, torture, and rape".

In Japan, extreme politeness, courtesy and kindness are the face of the country that most visitors see and appreciate so much. But there are other sides of Japan which are dark and sinister. This includes many shameful acts and practices which were highlighted by the United Nations Human Rights Committee (HRC) in 2014. ${ }^{34}$

For example, there is "widespread racist discourse against members of minority groups, such as Koreans, Chinese or Burakumin, inciting hatred and discrimination against them". Foreign trainees and technical interns are the subject of "a large number of reports of sexual abuse, labourrelated deaths and conditions that could amount to forced labour". And "a large number of persons with mental disabilities are subject to involuntary hospitalization."

It is of course true that obnoxious behavior exists in all countries. But it is the role of the state to legislate against such behavior and to enforce that legislation. The state should promote attitudes of tolerance, respect and openness. It should not be complicit in abuses of human rights. Unfortunately, the HRC notes that the Japanese government has "not made any progress to establish a consolidated national human rights institution".

The HRC had stern comments to make about one of the great tragedies of modern times, the Fukushima Daiichi nuclear disaster. This is now widely regarded as a man-made disaster, not a natural disaster, as a Japanese parliamentary commission argued convincingly. The HRC is concerned that former residents have no choice but to return to highly contaminated areas because of "the high threshold of exposure level" that the government set in Fukushima, as well as the decision to cancel some of the evacuation areas.

The committee also expressed serious concern about the Japanese government's contradictory position regarding the sexual slavery practices against "comfort women" by the Japanese military during wartime, as well as a lack of effective remedies available to them as victims of past human rights violations.

As Asia's most mature democracy, and a country sitting in the midst of great economic and political power transitions, Japan should not treat the 
HRC's report lightly. Its traditional approach of stonewalling is no longer viable. The HRC noted that many of its previous recommendations have not been implemented.

\section{Happiness and Asia’s Middle Class}

As Asia aspires to realize a middle-class society, it is important for policymakers to bear in mind that happiness and well-being are the most important measures of societal progress, not GDP alone. Disappointingly, most Asian countries score relatively poorly in the World Happiness Report ${ }^{35}$ compared with North America, Western Europe and Latin America. ${ }^{36}$

Within Asia, Southeast Asia is doing better than East Asia, which is ahead of South Asia. And while happiness has improved in Southeast and East Asia over the past decade, it has declined in South Asia. Moreover, happiness in Asia is always not well correlated with GDP per capita. In other words, some advanced countries score poorly, while other less advanced countries do quite well.

Singapore is Asia's most happy country, but is ranked only 26th in the world. Then Thailand (32nd) and Malaysia (42nd) come in well ahead of the more prosperous Japan (51st), Korea (55th) and Hong Kong (71st). Other Southeast Asian countries are further down the list- the Philippines 72nd, Indonesia 81st and Vietnam 94th. While from South Asia, Pakistan ranks 80th, Bhutan 97th, Nepal 99th, Bangladesh 110th, Sri Lanka 120th and India $122 \mathrm{nd}$. The case of China, ranked 79th, is particularly interesting. While China has enjoyed sharply growing per capita income over the past 25 years, happiness fell steadily from 1990 until about 2005, before since recovering to 1990 levels. Falling happiness is attributed to rising unemployment and fraying social safety nets.

Southeast Asia's positive edge was confirmed in a Gallup poll asking people if they experienced positive emotions the previous day, as Indonesia, the Philippines and Thailand come in at 12th, 13th and 14th in the world, way ahead of all other Asian countries. ${ }^{37}$ Much further down the list are China (31st), Japan (60th), India (78th) and Korea (95th). In another initiative, the Gallup-Healthways global well-being index,${ }^{38}$ four Southeast Asian countries, Myanmar, Malaysia, the Philippines and Thailand, are ranked in the top 50, while Japan is 92nd, Korea 117th, Hong Kong 120th and China 127th. 
In the OECD Better Life Index, ${ }^{39}$ the Japanese and Koreans are less satisfied with their lives than the OECD average, with particularly low scores for work-life balance and self-reported health.

In short, money doesn't necessarily buy happiness. Southeast Asian countries like Indonesia, Malaysia, the Philippines, Singapore and Thailand perform much better than wealthier countries of Northeast Asia.

While happiness and well-being are important life objectives, they can also be important for the economy and society. Happy people with high well-being are healthier, more productive and creative, and more resilient in the face of crises and shocks. And happy members of society can contribute to a rich civil society. Countries like Australia, Canada, Denmark, Germany, Sweden and the US highlight the importance of happiness and well-being to all aspects of economic, social and political life.

Asian government, business and civil society leaders must pay much greater attention to happiness and well-being, and not just economic growth. Indeed, as Asian societies are now maturing, happiness and wellbeing can provide a new path to economic prosperity, as well as social stability and harmony.

\section{The Rise of Asia’s Super Rich}

While the majority of Asians have barely escaped the clutches of extreme poverty, a super-rich elite is also blossoming. We cannot resist saying a few words on them.

As a delightful introduction to this bizarre world, nothing beats Kevin Kwan's novel "Crazy Rich Asians". ${ }^{40}$ It recounts the lives of three superrich, pedigreed Chinese families. And the gossip, backbiting and scheming that occurs when the heir to one of the most massive fortunes in Asia brings home his American-born Chinese (ABC) girlfriend to the wedding of the season.

When Rachel Chu agrees to spend the summer in Singapore with her boyfriend, Nicholas Young, she envisions a humble family home, long drives to explore the island, and quality time with the man she might one day marry. What she doesn't know is that Nick's family home happens to look like a palace, and that she'll spend more time in private jets than cars. And with one of Asia's most eligible bachelors on her arm, Rachel might well have a target on her back. 
Kwan introduces us to many of the super-rich stereotypes of the Asian century in this story of over-the-top consumerism, social excesses and jetsetting lives of the wealthiest and most snobbish families in Asia.

Here is a short sampling: Chuppies (Chinese yuppies); Hennessyswirling, cigar-puffing fat-cat Asian tycoons; Hong Kong fashionista men; marriage-scheming mothers, aunts and in-laws; fortune-hunting "Taiwanese tornadoes"; Henwees (high-net worth individuals); bitchy shopaholic parties; penny-pinching old-money overseas Asians; spendthrift new-money mainlander Chinese; and an Indian Singaporean who sends her saris back to New Delhi to be specially cleaned.

This is a story that reveals many of the social forces and tensions in Asia's rapidly changing society. Old money and new money. Overseas Chinese and Mainland Chinese. Generational divide between young Westernized Asians and their traditional parents. Snobbery attached to Asians who speak English with British rather than American accents. And more.

This is the world of at least some of Asia's super rich, the 412 Asian billionaires, who make up one-quarter of the world's 1694 billionaires. $^{41}$ Asia's leading super rich are China's Wang Jianlin (18th in the world), Hong Kong's Li Ka-shing (20th), Hong Kong's Lee Shau Kee (31st), China's Jack Ma (33rd) and India's Mukesh Ambani (36th).

Already China has 251 billionaires, placing it second on the global league table after the US, with India placed 6th and Hong Kong 8th. Even relatively poorer Asian countries like Indonesia, Malaysia, Thailand and the Philippines have their fair share of billionaires.

Even if Asia's super rich may not be a source of spiritual and cultural inspiration, they are certainly becoming drivers of the global economy, especially through their purchases of luxury products and international real estate, business and financial investments, and their children who attend international universities, sometimes showing off their Ferraris.

Indeed, China has been the engine of the global luxury goods market for a number of years now, especially for products, accessories and hard luxury items like watches and jewelry. Chinese consumers bought the largest portion of global luxury purchases (31\%), followed by Americans (24\%) and Europeans (18\%), according to one survey. ${ }^{42}$ Chinese shoppers spend far more abroad than in mainland China, which only accounts for $20 \%$ of their global purchases. In 2000, Japanese consumers accounted for more than one-quarter of global luxury purchases, but now they represent only $10 \%$.

But as some Asians have become super rich, Asia has also become the center of rich country problems. For example, the world is in the midst of 
a diabetes epidemic, as this condition has risen astronomically these past three decades. More than $60 \%$ of the world's 382 million people who suffer from diabetes come from Asia. ${ }^{43}$ Indeed, China has some 114 million adults with diabetes, and another 493 million with prediabetes, while India has 65 million with diabetes. And with obesity rising in Singapore, it is estimated that the city state will have half a million people with diabetes by 2020 and that this will rise to 1 million by 2050 .

Asia's rapid economic development has driven a dramatic improvement in Asian lives. But Asia is still suffering from stunted economic development, and the notion of middle-class Asia still remains a myth. In the following chapters, we examine the seven challenges that we believe are crucial for overcoming stunted economies and societies, and realizing an Asian century.

\section{Notes}

1. Mahbubani, Kishore (2014). The Expanding Middle Class in Asia. Huffington Post, 26 March 2014.

2. Asian Development Bank (2010). Key Indicators for Asia and the Pacific 2010. Special chapter on "The Rise of Asia's Middle Class".

3. Kharas, Homi (2010). The Emerging Middle Class in Developing Countries. OECD Development Centre, Working Paper No. 285.

4. World Bank. Poverty \& Equity Data. http://povertydata.worldbank.org/ poverty/home/. Accessed 8 September 2016.

5. PewResearchCenter (2015). A Global Middle Class is More Promise than Reality.

6. Choi, Seong-keun, and Jun-hyup Lee (2015). Changes in the Quality of Life of Korea's Middle Class. Korea Focus.

7. World Bank and IMF (2015). Global Monitoring Report 2015/2016: Development Goals in an Era of Demographic Change.

8. These 15 countries are Chad, Ethiopia, The Gambia, Ghana, GuineaBissau, Malawi, Mali, Mozambique, Nepal, Niger, Rwanda, Sierra Leone, Tajikistan, Tanzania and Uganda.

9. Schauer, V., Kalpana Kochhar, Shi Piao, Sonali Jain-Chandra, Tidiane Kinda. Sharing the Growth Dividend: Analysis of Inequality in Asia. IMF Working Paper No. 16/48.

10. Ofreneo, Rene E. (2013). Asia and the Pacific: Advancing Decent Work Amidst Deepening Inequalities. 
11. Asian Development Bank (2011). Key Indicators for Asia and the Pacific 2011. Special Chapter: Toward Higher Quality Employment in Asia.

12. Standing, Guy (2014). The Precariat: The New Dangerous Class.

13. Collins, Daryl, Jonathan Morduch, Stuart Rutherford, and Orlanda Rithven (2009). Portfolios of the Poor: How the World's Poor Live on \$2 a Day.

14. Economist Intelligence Unit. Worldwide Cost of Living Report 2017.

15. Mahbubani, Kishore. Following Singapore's lead on the road of development. Earth Times, 15 January 2001.

16. OECD. Economic Survey of Japan 2017.

17. OECD. Inequality and Income Data.

18. DW (2014). Why sanitation in Asia requires more than just toilets. Interview with Jingmin Huang, Senior Urban Development Specialist, South Asia Department, Asian Development Bank.

19. WaterAid (2015). The State of the World's Toilets 2015.

20. Asian Development Bank (2014). Key Indicators for Asia and the Pacific 2014. Special Chapter: Poverty in Asia: A Deeper Look.

21. UNESCAP (2015). Overview of Natural Disasters and their Impacts in Asia and the Pacific, 1970-2014.

22. Centre for Research on the Epidemiology of Disasters, and United Nations Office for Disaster Risk Reduction (2015). The Human Cost of Weather Related Disasters 1995-2015.

23. Asian Development Bank. Development Asia, "Dealing with Disasters". January-March 2011.

24. 22nd Pacific Economic Cooperation Council General Meeting, Beijing, China, 10-11 September 2014.

25. OECD and UNESCO (2016). Education in Thailand-an OECDUNESCO Perspective.

26. OECD (2015). Education in Indonesia-rising to the challenge.

27. Barro, R., and J.W. Lee. (2010). A New Data Set for Education Attainment in the World, 1950-2010. Working. ADB Economics Working Paper Series No. 216.

28. McKinsey\&Co (2014). Offline and falling behind: Barriers to Internet adoption.

29. Bohannon, John (2016). Who is getting left behind in the Internet revolution. Science Magazine, 9 September 2016.

30. Freedom House. Freedom on the Net 2016.

31. Amnesty International Report 2015/16. The State of the World's Human Rights.

32. Human Rights Watch (2016). World Report 2016.

33. US Department of State (2015). Country Reports on Human Rights Practices for 2015. 
34. United Nations Human Rights Committee (2014). Concluding observations on the sixth periodic report of Japan, 23 July 2014.

35. Helliwell, J., R. Layard, \& J. Sachs. World Happiness Report 2017.

36. This report measures happiness based on six factors: GDP per capita, healthy years of life expectancy, social support (as measured by having someone to count on in times of trouble), trust (as measured by a perceived absence of corruption in government and business), perceived freedom to make life decisions, and generosity (as measured by recent donations).

37. Gallup (2014). People worldwide are reporting a lot of positive emotions, 21 May 2014.

38. Gallop-Healthways (2015). Country Well-Being Rankings.

39. OECD Better Life Index (accessed 13 September 2016).

40. Kwan, Kevin (2013). Crazy Rich Asians.

41. Forbes (2016). The World's Billionaires, 2016 Ranking.

42. Bain \& Company (2015). Luxury Goods Worldwide Market Study. FallWinter 2015.

43. Nanditha, Arun, Ronald C.W. Ma, Ambady Ramachandran, Chamukuttan Snehalatha, Juliana C.N. Chan, Kee Seng Chia, Jonathan E. Shaw and Paul Z. Zimmet (2016). Diabetes in Asia and the Pacific: Implications for the Global Epidemic. Diabetes Care, 39 (9). American Diabetes Association.

Open Access This chapter is licensed under the terms of the Creative Commons Attribution 4.0 International License (http://creativecommons.org/licenses/ by $/ 4.0 /)$, which permits use, sharing, adaptation, distribution, and reproduction in any medium or format, as long as you give appropriate credit to the original author(s) and the source, provide a link to the Creative Commons license and indicate if changes were made.

The images or other third party material in this chapter are included in the chapter's Creative Commons license, unless indicated otherwise in a credit line to the material. If material is not included in the chapter's Creative Commons license and your intended use is not permitted by statutory regulation or exceeds the permitted use, you will need to obtain permission directly from the copyright holder.

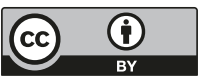

